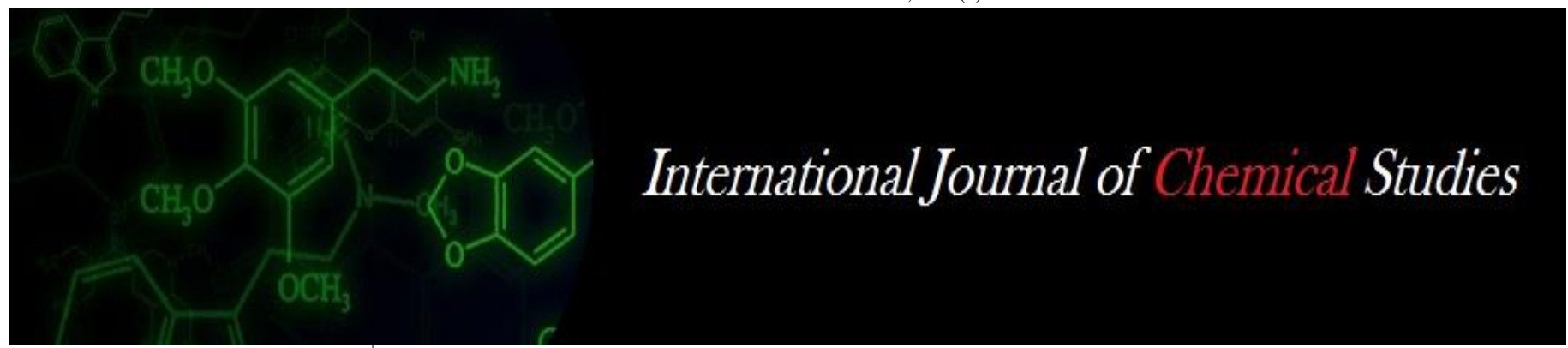

P-ISSN: 2349-8528

E-ISSN: 2321-4902

www.chemijournal.com

IJCS 2020; SP-8(5): 188-190

(C) 2020 IJCS

Received: 16-07-2020

Accepted: 18-08-2020

\section{Suvarna Pati}

Regional Horticultural Research and Extension Centre, Dharwad, Karnataka, India

\section{Arunkumar B}

Regional Horticultural Research and Extension Centre, Dharwad, Karnataka, India

Renuka H

Kittur Rani Chennamma College of Horticulture, Arabhavi,

Karnataka, India

\section{Poornima H}

Department of Entomology,

University of Horticultural

Sciences, Bagalkot, Karnataka,

India

\section{Shridhar D}

Regional Horticultural Research and Extension Centre, Dharwad, Karnataka, India

\section{Padanad LA}

Regional Horticultural Research and Extension Centre, Dharwad, Karnataka, India
Corresponding Author:

Suvarna Patil

Regional Horticultural Research and Extension Centre, Dharwad, Karnataka, India

\section{Evaluation of IPM modules against shoot and fruit borer in Okra}

\author{
Suvarna Patil, Arunkumar B, Renuka H, Poornima H, Shridhar D and \\ Padanad LA
}

DOI: https://doi.org/10.22271/chemi.2020.v8.i5d.10539

\begin{abstract}
Okra (Abelmoschus esculentus) locally known as 'Bhendi' or 'Dherosh' also known as lady's finger is a popular and most common annual vegetable crop grown from seed in India and in other tropical and subtropical parts of the world. Several insect pests have so far been recorded to attack okra but okra shoot and fruit borer, is the most destructive insect pest responsible for considerable damage inflicting yield loss up to $40-50 \%$ or more. Now-a-days, IPM has been attaining immense importance in the agricultural scenario of India. Hence formulation of a sustainable IPM module was felt necessary to manage this pest. The experiment was conducted at Regional Horticultural Research and Extension Centre, Dharwad during khariff season of 2017-18 ans 2018-19. There were five modules, M-I: Bio- intensive module, (100\% organic): Azardirachtin 10000ppm@1.0mlL, Lecanicillium (Verticillium)lecani@5g/L, Bt @ $1 \mathrm{ml} / \mathrm{L}$, Beauveria bassiana $5 \mathrm{~g} / \mathrm{l}$. The treatments in the IPM module M-II comprised of Azardirachtin 10000ppm@1.0mlL, Lecanicillium (Verticillium) lecani@5g/L, Chlorantrinilipole 20 SC @0.25m1/L. M-III: Chemical module (100\% chemical): Azardirachtin 10000ppm@1.0mlL Dimethoate@1.7ml/L, Thiamethoxam 25 WG @ 0.2g/L, Chlorantrinilipole 20 SC @0.25ml/L. M-IV: POP : Quinalphos 25 EC @ 2.0ml/L. M-IV: Quinalphos. M-V: Untreated control. The observed percent fruit damage and pooled analysis of 2017-18 and 2018-19 revealed that the percent mean shoot and fruit borer infestation during fruiting phase was 9.49 in IPM module (M-II). The chemical module recorded significantly lesser fruit infestation (7.24). The IPM module recorded 14.14 tonnes/ha fruit yield with highest B:C ratio against shoot and fruit borer. Further, highest B:C ratio (3.71) was recorded in M-II followed by M-III (3.55) and M-I (1.91). Hence, M-I in comparison with M-II and M-III seemed to be a quite promising strategy as it did not require much insecticidal interference, reduced of insecticidal residue problem and safe to bees and natural enemies.
\end{abstract}

Keywords: Okra, IPM modules, shoot and fruit borer management

\section{Introduction}

Okra (Abelmoschus esculentus) locally known as 'Bhendi' or 'Dherosh' also known as ladies finger, bhindi, bamia, okro orgumbo in different parts of the world. It belongs to the family Malvaceae and originated in tropical Africa. Though okra is produced mainly in the kharif season it can be grown year round. It is cooked in a variety of ways and used as an ingredient in a wide variety of dishes. Young tender leaves are used as a leafy vegetable in some parts of the world. The ripe seeds are roasted, ground and used as substitute for coffee in Turkey (Mehta, 1959) ${ }^{[9]}$. The roots and stem are used for clearing the cane juice from which gur or brown sugar is prepared (Chauhan, 1972) ${ }^{[3]}$. Its medicinal value has also been reported in curing ulcer and relief from haemorrhoids (Adams, 1975) ${ }^{[1]}$. It is mainly grown in India, Nigeria, Sudan, Pakistan, Ghana, Egypt, Saudi Arabia, Mexico and Cameroon. In India, it is grown in an area of 0.50 million ha with an annual production of 6.09 million tonnes and with productivity of about 12.00 million tonnes per hectare (Horticulture glance 2018) ${ }^{[6]}$.

One of the important limiting factors in the cultivation of okra is insect pests. The crop, right from germination to harvesting is attacked by about 72 species of insect pests (Rao and Rajendran, 2003) ${ }^{[10]}$. Among them, the shoot and fruit borer (E. insulana and E. vittella) is one of the most serious pests of okra. The attack of fruit borer, Earias vittella on okra starts 45 weeks after the germination both in the kharif and summer seasons. The larvae bore into the terminal growing shoots, floral buds, flowers and fruits of okra, resulting in cessation, withering and drying of infested shoots, tender leaves and heavy shedding of floral buds and 
flowers. The infested fruits become malformed and are rendered unfit for human consumption as well as for procurement of the seeds. The borer has been reported to cause 24.6 to 26.0 per cent damage to okra shoots (Zala et al., $1999)^{[17]}$ and 40 to 100 per cent loss to fruits (Shinde et al., 2007) ${ }^{[12]}$. Krishnaiah (1980) ${ }^{[7]}$ observed the attack of fruit borer to the extent of $35 \%$ in harvestable fruit of okra. The chemical control has been suggested by many workers to combat with the insect pests of okra (Manjanaik et al., 2002) ${ }^{[8]}$ but due to one or other reasons, could not become panacea in protection of the crop.

The use of insecticides have undoubtedly resulted in the maximum production but the proliferation of insecticides and their unilateral utilization have created many problems such as development of resistance in insect pests to insecticides, resurgence of insect pests, outbreak of secondary insect pests, insecticidal residues, detrimental effect to environment, pollinators, natural enemies, as well as to human health. Today there is a great demand for safer and more ecologically acceptable pest management module for IPM programs affecting specifically harmful pests, while sparing beneficial insect species and pollinators. With the above views the present study makes an attempt to test the effectiveness of different pest management modules for controlling E. Vittella (Fab.) in okra. Keeping the point in view, field trials on management of shoot and fruit borer through different newer and biorational insecticides in okra was conducted.

\section{Materials and Methods}

Investigation on evaluation of different IPM modules against shoot and fruit borer was carried out at the Regional Horticultural Research and Extension Centre, Kumbapur, Dharwad during 2017-18 and 2018-19. The experiment was laid out in simple randomized block design (RBD) with five treatments including untreated control, each replicated four times. The plot size was kept $3.0 \times 3.0 \mathrm{~m}^{2}$ keeping row to row and plant to plant distance of 60 and $45 \mathrm{~cm}$, respectively. The okra variety, Arka Anamika was used in the experiment and was sown in Khariff season of 2017 and 2018. The recommended agronomical practices were followed to raise the crop. Treatment-wise application of botanicals and insecticides was given at ETL of fruit damage i.e. $5 \%$ fruit damage by using high volume knapsack sprayer with required concentration. Subsequent spray was given on need based during both the seasons of experimentation. Two foliar sprays of all the insecticides were given at two weeks interval. The spray was done by using knap sack sprayer. Utmost care was taken to check the drift of insecticides by putting polythene check screen around each plot at the time of spraying. The quantity of water used for plot was increased depending on the growth of the crop. The quantity of spray solutions required for full coverage in first and second nsecticidal application were 500 litres per hectare. The data on shoot and fruit borer, Earias spp. were recorded on five randomly selected and tagged plants throughout the crop period. The per cent fruit damage was recorded at each picking during two consecutive years. The per cent infestation of fruits on number basis was calculated by counting the infested and healthy fruits separately from selected tagged plants per treatment by replication-wise before picking as well as after each picking.

The pooled data on per cent infestation of fruits of okra (kharif, 2017 and kharif, 2018) were transformed into angular values and subjected to analysis of variance. The healthy fruits of all the pickings in each treatment were pooled together to work out the total yield. The per cent fruit damage was calculated by counting the healthy and damaged fruits from net plot area on number as well as weight basis and per cent fruit damage was worked out by using the following formula. The yield of marketable okra fruits from each treatment was recorded at each picking separately. The yield obtained from net plot area was converted into quintal per hectare.

Number of damaged fruits $\%$ Fruit infestation (Number basis) $=$

Total number of fruits

\section{Statistical analysis}

The data on number of larva (e) per plant and per cent fruit damage were subjected to square root and arcsine transformation, respectively and statistically analysed by ANOVA and means were separated using LSD test at 5\% level of significance for interpretation by following standard statistical technique (Steel and Torrie, 1980) ${ }^{[15]}$.

Table 1: Treatment combinations and their respective symbols

\begin{tabular}{|c|c|c|}
\hline S. No & Module & Components of module \\
\hline 1 & M-I & $\begin{array}{c}\text { Bio- intensive module, (100\% organic) : Azardirachtin 10000ppm@1.0ml/L, Lecanicillium lecani @ 5g/L, Bt } \\
@ 1 \mathrm{ml} / \mathrm{L}, \text { Beauveria bassiana @ } 5 \mathrm{~g} / \mathrm{L} .\end{array}$ \\
\hline 2 & M-II & $\begin{array}{c}\text { IPM based module }(50 \% \text { organic }+50 \% \text { chemical }): \text { Azardirachtin 10000ppm @ 1.0mlL, Lecanicillium lecani @ } \\
5 \mathrm{~g} / \mathrm{L}, \text { Chlorantriniliprole } 20 \mathrm{SC} @ 0.25 \mathrm{ml} / \mathrm{L}\end{array}$ \\
\hline 3 & M-III & $\begin{array}{c}\text { Chemical module (100\% chemical): Azardirachtin 10000ppm@ @ 1.0ml/L, Dimethoate 30\% EC @ 1.7ml/L, } \\
\text { Thiamethoxam 25 WG @ 0.2g/L, Chlorantriniliprole } 20 \mathrm{SC} @ 0.25 \mathrm{ml} / \mathrm{L} .\end{array}$ \\
\hline 4 & M-IV & Quinalphos 25 EC @ 2.0ml/L \\
\hline 5 & $\mathrm{M}-\mathrm{V}$ & Untreated control \\
\hline
\end{tabular}

\section{Results and Discussion}

Based on the pooled data of Kharif 2018 and Kharif 2019 the treatment M-III, Chemical module was found to be the most effective which recorded least percentage of fruit damage (7.24) followed by M-II i.e IPM based module with 9.49 per cent fruit damage and M-I with 12.37 per cent fruit damage and were significantly superior to M-IV, check (14.88) and untreated control M-V(20.32). Sprays of Achook (1\%) and neem oil $(1 \%)$ were provided good result to manage $E$. vittella in okra at Jabalpur, Madhya Pradesh (Shukla et al., 1996) ${ }^{[13]}$.
Dhanalakshmi and Mallapur (2010) ${ }^{[5]}$ reported emamectin benzoate 5 SG @0.2 g/l (7.82\% damage) as most effective insecticide followed by spinosad 45 SC @ $0.1 \mathrm{ml} / 1(9.9 \%$ damage) and indoxacarb 14.5 SC @ 0.3 ml/l (10.74\% damage) against fruit borer of okra, to some extent corroborate with the present findings of Dhaka et al., (2016) ${ }^{[4]}$. Ayyangar and Rao (1989) ${ }^{[2]}$ and Sarkar et al., (2015) ${ }^{[11]}$ proved that the azadirachtin found to be good botanical insecticide to manage fruit boring pests in okra. According to Yadav et al., (2008) ${ }^{[16]}$, application of Bt-neem formulation 
with azadirachtin-endosulfan-Trichogramma at 15 days intervals reduced the fruit and shoot borer infestation up to $1.93 \%$ with the maximum yield $(79.70 \mathrm{q} / \mathrm{ha})$. Ayyangar and Rao (1989) ${ }^{[2]}$ have reported that azadirachtin played a major role in controlling the insect pests by adversely affecting the consumption and utilization of plant parts by the pests. In present study, the observed percent fruit damage and pooled analysis of 2017-18 and 2018-19 revealed that the percent mean shoot and fruit borer infestation fruiting phase was 9.49 in IPM module (M-II) but in chemical module recorded significantly lesser fruit infestation (7.24). The IPM module recorded 14.14 tonnes/ha fruit yield with highest $\mathrm{B}: \mathrm{C}$ ratio against shoot and fruit borer. Further, highest B:C ratio was recorded in M-II followed by M-III. Hence, M-II in comparison M-III seemed to be a quite promising strategy as it did not require much insecticidal interference, reduced of insecticidal residue problem and safe to bees and natural enemies.

Table 2: Pooled Per cent fruit damage on okra during 2018-19 and 2019-20

\begin{tabular}{|c|c|c|c|c|c|c|c|c|c|}
\hline S. No & Treatments & \multicolumn{7}{|c|}{ Per cent fruit damage on okra } & \multirow{2}{*}{ Fruit yield / Ha } \\
\hline & & Before spray & 1 pick & 2 pick & 3 pick & 4 pick & 5 pick & Mean & \\
\hline 1 & M-I & $\begin{array}{c}21.20 \\
(27.32)\end{array}$ & $\begin{array}{c}13.43 \\
(21.45)\end{array}$ & $\begin{array}{c}12.71 \\
(20.87)\end{array}$ & $\begin{array}{c}9.00 \\
(17.41)\end{array}$ & $\begin{array}{c}13.02 \\
(21.14)\end{array}$ & $\begin{array}{c}13.67 \\
(21.67)\end{array}$ & 12.37 & 8.82 \\
\hline 2 & M-II & $\begin{array}{c}19.56 \\
(26.14)\end{array}$ & $\begin{array}{c}10.93 \\
(19.29) \\
\end{array}$ & $\begin{array}{c}9.72 \\
(18.15) \\
\end{array}$ & $\begin{array}{c}6.44 \\
(14.68) \\
\end{array}$ & $\begin{array}{c}9.73 \\
(18.16) \\
\end{array}$ & $\begin{array}{c}10.62 \\
(19.00) \\
\end{array}$ & 9.49 & 14.30 \\
\hline 3 & M-III & $\begin{array}{c}20.59 \\
(26.90)\end{array}$ & $\begin{array}{c}8.70 \\
(17.13)\end{array}$ & $\begin{array}{c}7.49 \\
(15.85)\end{array}$ & $\begin{array}{c}4.21 \\
(11.79)\end{array}$ & $\begin{array}{c}7.63 \\
(15.98)\end{array}$ & $\begin{array}{c}8.19 \\
(16.56)\end{array}$ & 7.24 & 14.67 \\
\hline 4 & M-IV & $\begin{array}{c}21.12 \\
(27.32)\end{array}$ & $\begin{array}{c}16.75 \\
(24.13)\end{array}$ & $\begin{array}{c}14.01 \\
(21.94)\end{array}$ & $\begin{array}{c}10.49 \\
(18.87)\end{array}$ & $\begin{array}{c}16.76 \\
(24.10)\end{array}$ & $\begin{array}{c}16.39 \\
(23.84)\end{array}$ & 14.88 & 7.42 \\
\hline 5 & $M-V$ & $\begin{array}{c}20.33 \\
(26.77)\end{array}$ & $\begin{array}{c}22.01 \\
(27.94)\end{array}$ & $\begin{array}{c}20.26 \\
(26.73)\end{array}$ & $\begin{array}{c}16.25 \\
(23.77)\end{array}$ & $\begin{array}{c}20.86 \\
(27.16)\end{array}$ & $\begin{array}{c}22.23 \\
(28.11)\end{array}$ & 20.32 & 5.39 \\
\hline 6 & SEm+ & NS & 0.72 & 0.55 & 0.55 & 0.62 & 0.67 & & 0.69 \\
\hline 7 & CD @ 5\% & & 2.21 & 1.70 & 1.71 & 1.90 & 2.08 & & 2.21 \\
\hline
\end{tabular}

Note: Figures in parentheses are retransformed values; those outside are arcsine transformed values

Table 3: Benefit: Cost ratio of biopesticides and insecticides used against okra shoot and fruit borer during 2018-19 and 2019-20

\begin{tabular}{|c|c|c|c|c|c|c|c|c|}
\hline $\begin{array}{c}\text { S. } \\
\text { No }\end{array}$ & Treatments & $\begin{array}{c}\text { Marketable fruit } \\
\text { yield (t/ha) }\end{array}$ & $\begin{array}{c}\text { Total returns } \\
\text { (Rs./ha) }\end{array}$ & $\begin{array}{c}\text { Cost of cultivation } \\
\text { (Rs./ha) }\end{array}$ & $\begin{array}{c}\text { Cost of insecticide } \\
\text { (Rs./ha) }\end{array}$ & $\begin{array}{c}\text { Total cost of } \\
\text { cultivation (Rs./ha) }\end{array}$ & $\begin{array}{c}\text { Net returns } \\
\text { (Rs./ha) }\end{array}$ & $\begin{array}{c}\text { Benefit } \\
\text { Cost ratio }\end{array}$ \\
\hline 1 & M-I & 8.82 & $1,76,400$ & 58,600 & 2,100 & 60,700 & $1,15,700$ & 1.91 \\
\hline 2 & M-II & 14.30 & $2,86,000$ & 58,200 & 2,500 & 60,700 & $2,25,300$ & 3.71 \\
\hline 3 & M-III & 14.70 & $2,93,400$ & 59,000 & 5,500 & 64,500 & $2,28,900$ & 3.55 \\
\hline 4 & M-IV & 7.42 & $1,48,400$ & 57,800 & 1,300 & 59,100 & 89,300 & 1.51 \\
\hline 5 & M-V & 5.39 & $1,07,800$ & 57,000 & - & 57,000 & 50,800 & 0.89 \\
\hline
\end{tabular}

\section{References}

1. Adams CF. Nutritive value of American foods in common units. U. S. Department of Agriculture, Agriculture Handbook, 1975; 425:29.

2. Ayyangar GSG, Rao PJ. Azadirachtin effects on consumption and utilization of food and midgut enzymes of Spodoptera litura Fab. Ind. J Ent., 1989; 51(4):373376.

3. Chauhan DVS. Vegetable production in India (3 rd ed.). Ram Prasad and Sons, Agra. Anonymous. 2017. Horticultural statistics at a glance; http://nhb.gov.in, 1972.

4. Dhaka SS, Rai MK, Kumar A. Relative efficacy of novel insecticidesand biopesticides against Earias vittella (Fab.) in okra. Ann. Pl. Prot. Sci. 2016; 24(2):271-275.

5. Dhanalakshmi DN, Mallapur CP. Evaluation of new promising molecules against fruit borers in okra. Int J Pl Protec. 2010; 3:268-270.

6. Horticulture at Glance: www.agricoop.nic.in

7. Krishinaiah K. Methodologist for assessing crop losses due to pests of vegetables" Assessment of crop losses to pest and diseases". Ed. Govindu. H. C. et al. USA Tech. Series. 1980; 33:259-67.

8. Manjanaik C, Herle PS, Singh GK. Chemical control of fruit borer, Earias spp. in coastal zone of Karnataka, Environmental Science of Ecology. 2002; 20(3):692-695.

9. Mehta YR. Vegetable growing in Uttar Pradesh. Rockefeller Foundations, Bureau of Agriculture Information. Lucknow, Utter Pradesh, India, 1959.
10. Rao S, Rajendran R. Joint actionpotential of neem with other plantextracts against the leafhopper Amrascadevastans (Distant) on okra. Pest Management and Economic Zoology, 2003; 10:131-136.

11. Sarkar S, Patra S, Samanta A. Evaluation of biopesticides against redcotton bug and fruit borer of okra. The Bioscan, 2015; 10(2):601-604.

12. Shinde BD, Sarkate MB, Memade PW, Sable YR. Bioefficacy of botanical microbial and synthetic insecticides against okra fruit borer. Pestology. 2007; 31(3):19-22.

13. Shukla A, Pathak SC, Agarwal RK. Efficacy of some insecticides and plant products against the infestation of okra shoot and fruit borer, Earias vittella Fab. Crop Res. 1996; 12(3):367-373.

14. Srinivasan K, Krisnakumar NK. Studies of on the extent of loss and economics of pest management in okra. Trop. Pest Manage. 1983; 29(4):363-370.

15. Steel RGD, Torrie JH. Principles and procedures of statistics. McGraw-Hill Book Company, New York, 1980.

16. Yadav JB, Singh RS, Tripathi RA. Evaluation of biopesticides against pest complex of okra. Ann. Pl. Prot. Sci. 2008; 16(1):58-61.

17. Zala SP, Patel JR, Patel NC. Impact of weather on magnitude of Earias vittella (Fab.) infesting okra Indian Journal of Entomology. 1999; 61(4):351-355. 